\title{
Activin Receptor Type-1C
}

National Cancer Institute

\section{Source}

National Cancer Institute. Activin Receptor Type-1C. NCI Thesaurus. Code C96021.

Activin receptor type-1C (493 aa, $\sim 55 \mathrm{kDa}$ ) is encoded by the human ACVR1C gene. This protein plays a role in both cytokine signaling and serine/threonine phosphorylation. 